\title{
MULTILATERÁLIS KERESKEDÉSI PLATFORMOK EURÓPÁBAN ÉS MAGYARORSZÁGON ${ }^{1}$
}

Klis Krisztián - Vidovics-Dancs Ágnes

Tanulmányunkban először a multilaterális kereskedési platformok fejlődését mutatjuk be nemzetközi példákon keresztül. Ehhez kapcsolódóan három, már működő multilaterális kereskedési piacot - a lengyelt, az angolt és a skandinávot - jellemezzük és hasonlítjuk össze. Bemutatjuk a magyar piac gazdasági és jogi hátterét, valamint összegezzük, hogy milyen forrásbevonási kihívásokkal küzd a hazai kis- és középvállalati szektor. Majd magyar példán keresztül - közismert nevén BÉT Xtend - mutatjuk be a multilaterális kereskedési piac szereplöit, működését.

JEL-kódok: G1, G2, G3

Kulcsszavak: multilaterális kereskedési rendszer, BÉT Xtend, kis- és középvállalkozások

\section{MULTILATERÁLIS KERESKEDÉSI RENDSZER}

A „multilaterális kereskedési rendszer” kifejezés az angol Multilateral Trading Facility (MTF) kifejezésből származik. A fogalmat a 2004-es, MiFID néven ismertté vált EU-direktíva hívta életre a következő definícióval: „valamely befektetési vállalkozás vagy piacmüködtető által müködtetett multilaterális rendszer, amely pénzügyi eszközökre irányuló több harmadik fél vételi és eladási szándékát hozza össze - a rendszerben és megkülönböztetés-mentes szabályoknak megfelelöen - oly módon, hogy az szerzödést eredményez." (EU, 2004, 4/15.)

Az MTF tehát egy olyan elektronikus kereskedési rendszer, amely megkönnyíti a pénzügyi eszközök cseréjét. Az USA és Kanada szabályozásában hasonló platformokat takar az alternatív kereskedési rendszer (Alternative Trading System - ATS) elnevezés is. ${ }^{2}$ Lényegében a tőzsdék kistestvérének is lehetne nevezni

1 Szeretnénk megköszönni Máté-Tóth Istvánnak, a Budapesti Értéktőzsde kereskedéséért és üzletfejlesztéséért felelős vezérigazgató-helyettesnek, valamint Paulovits Mártonnak, a Kibocsátói Akvizíciók Igazgatóság igazgatójának kitartó és segítőkész munkájukat. A velük készített személyes interjúkon elhangzottakat több helyen felhasználtuk a cikkben

2 Sokszor szinonimaként is használják a két kifejezést. 
ezeket az MTF-platformokat, amelyeken keresztül általában olcsóbb és kedvező feltételek mellett lehetséges a piacra lépés és a jelenlét. A két kereskedési helyszín megkülönböztetését olykor nehezíti, hogy a tőzsdék is müködtethetnek (és több esetben müködtetnek is) MTF-t, befektetési tevékenységet folytató vállalkozás viszont csak MTF-t működtethet, tőzsdét nem.

Annak ellenére, hogy az MTF kifejezést csak a MiFID-direktíva kodifikálta, MTF-piacok már több évtizede léteznek. A legismertebbek és legsikeresebbek az alábbiak: Alternative Investment Market (továbbiakban AIM, Egyesült Királyság, 1995), TSX Venture Exchange (Kanada, 1999), Nasdaq First North (skandináv országok, 2005), NewConnect (Lengyelország, 2007) és ChiNext (Kína, 2009).

Az európai MTF-piacok mérete egyelőre nem közelíti meg a hagyományos tőzsdékét - 2018 augusztusában az európai prémium tőzsdék forgalma közel 800 milliárd euró volt, míg az MTF-piacoké 6,5 milliárd euró -, mégis érdemes megismerkedni ezekkel a piacokkal. 2017 óta már Magyarországon is van MTF-piac, amely BÉT Xtend néven biztosít kedvezményes tőzsdére lépési lehetőséget fejlett kkv-k számára.

A 3. fejezetben a magyar példán keresztül mutatjuk be részletesen, hogyan épül fel egy MTF-piac, aminek kontextusba helyezéséhez röviden jellemzünk három európai (lengyel, skandináv és angol) alternatív kereskedési platformot, némi betekintést nyújtva ezen európai piacok kialakulásába és fejlődésébe kontinensünkön. Ezekben a platformokban az a közös, hogy a kis- és középvállalkozások számára kívánnak olyan nyilvános piacot biztosítani, amelyek hasonlóan müködnek, mint a hagyományos és egyben szabályozott tőzsdék, azonban az újonnan belépő kibocsátók számára kedvezőbb feltételeket biztosítanak, amelyeket a 4. és 5. fejezetekben részletesen is kifejtünk.

A NewConnect lengyel MTF-piacot a Varsói Értéktőzsde indította el 2007. augusztus 30-án nagy növekedési potenciállal rendelkező kis- és középvállalkozások számára. A NewConnect létrehozásakor mintaként szolgált az akkor már jó ideje működő londoni AIM, amelyhez hasonlóan a NewConnect a tőzsdei forrásbevonás egy reális alternatívájává kívánt válni a kkv-szektorban. Technikailag ez a piac is hasonlóan szabályozott, mint a hagyományos tőzsdék, a piacra lépési és forgalomban tartási kritériumok azonban enyhébbek, a díjak kedvezőbbek (Asyngier, 2014). A kezdeti időszak dinamikus növekedése után az elmúlt években 400 körüli a NewConnectre bevezetett cégek száma (1. 1. ábra). 


\section{1. ábra}

\section{A NewConnect piacon regisztrált cégek száma (2007-2018)}

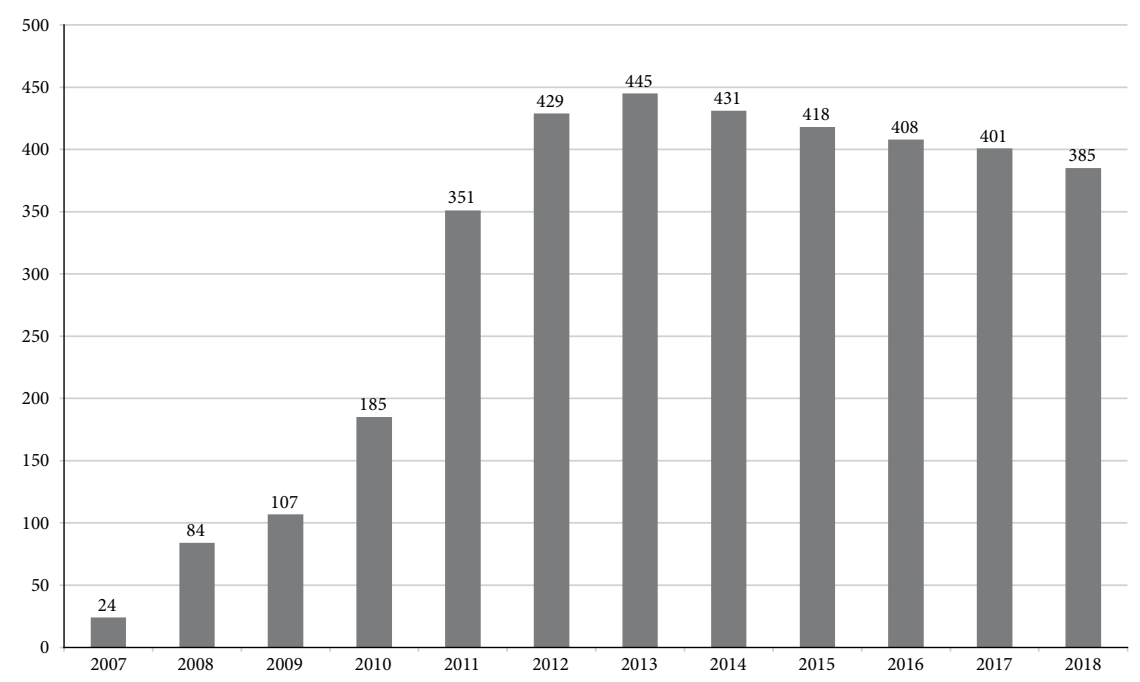

Forrás: saját szerkesztés a NewConnect (2019a) adatai alapján

A Nasdaq First North multilaterális kereskedési rendszer 2005-ben Dániából indult, ám 2006-ban megvette a svéd tőzsde - a Nasdaq Nordic -, így Stockholmba települt a központja. A skandináv MTF-piacként emlegetett struktúra jelenleg már magába foglalja a dán, a svéd, a litván, a lett, az örmény és 2006 óta a finn és az izlandi tőkepiacokat is. (Nasdaq OMX Nordic, 2018). A Nasdaq First North az angol és a lengyel MTF-piac mellett Európa egyik legdinamikusabban fejlödő kkv-piaca, 2019 májusában 580 regisztrált céggel rendelkezett. (Nasdaq First North, 2019a).

A londoni Alternative Investment Market 1995-ös alapítású, ez az egyik legrégebbi MTF-piac. A mindössze 10 vállalattal induló AIM már az alapítás évének végén 121 regisztrált vállalkozással rendelkezett, jelenleg a világ legnagyobb és legsikeresebb kkv-piaca (London Stock Exchange, 2018a). A 2. ábrán az AIMpiacra belépő szereplők száma látható éves szinten. A 2008-as válság begyürüzéséig dinamikusan fejlődött az újonnan AIM-re lépő cégek száma, amely 20052006 között érte el csúcsát. A válság megfékezte ugyan az AIM növekedését, de éves szinten átlagosan azóta is 65 brit és 21 más nemzetiségü kis- és középvállalkozás lép be erre a piacra. 2018-as adatok alapján a londoni prémium tőzsde 2168 cége közül 942 vállalkozás az MTF-piacra volt bejegyezve (London Stock Exchange, 2019a). 


\section{2. ábra}

Az AIM-piacra újonnan belépő cégek száma (2007-2018)

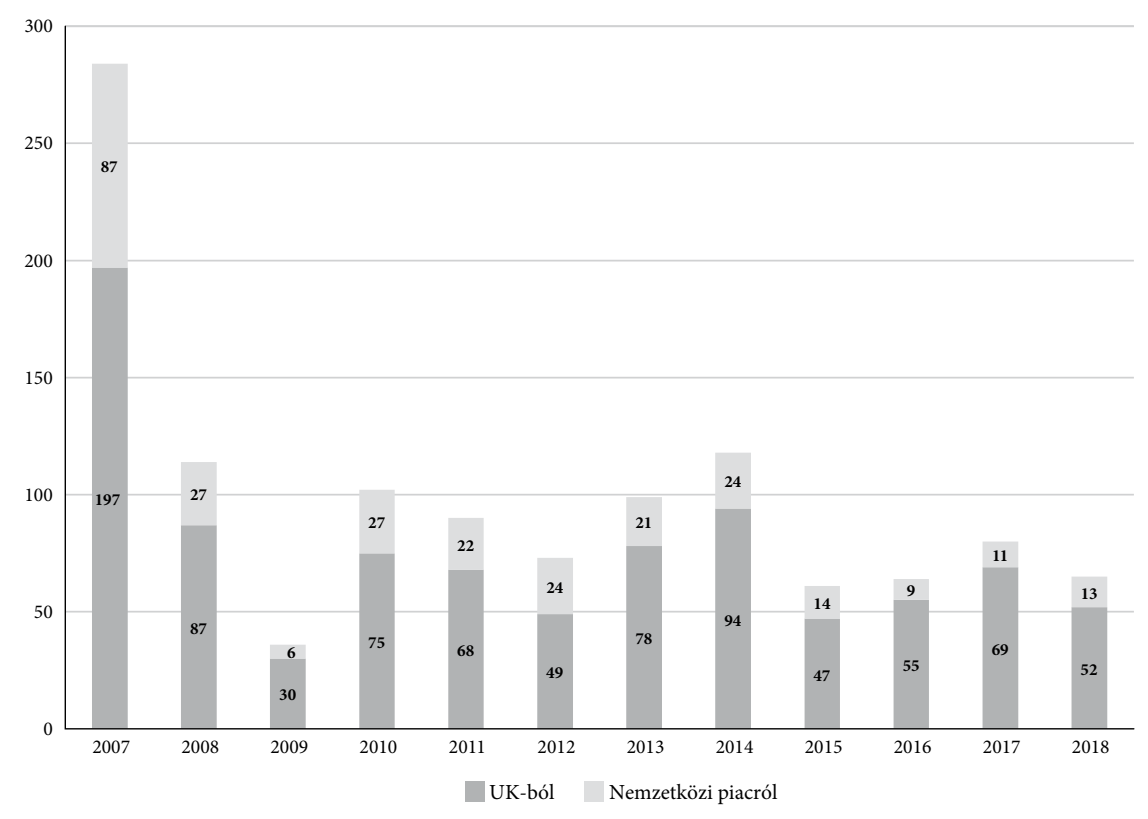

Forrás: saját szerkesztésű ábra

Adatok forrása: (London Stock Exchange (2019a)

Az AIM sikerében nagy szerepe volt annak, hogy a London Stock Exchange 2010 februárjában többségi tulajdont szerzett a Turquoise-ban, amely Európa addigi legnagyobb multilaterális kereskedési rendszere, széles európai ügyfélkörrel rendelkezik, a feltörekvő piacok közül többek között Magyarországgal és a Cseh Köztársasággal is kapcsolatban áll. Ennek köszönhetően a tagok 19 európai ország részvényeit, letéti igazolásait, tőzsdén kereskedett befektetési alapok (Exchange Traded Fund - ETF) jegyeit, illetve ugyanennyi ország európai opciós jogait forgalmazhatja, a tagjai közé bankok, brókerek, szakkereskedők és kiskereskedelmi közvetítők tartoznak (London Stock Exchange, 2018b).

A London Stock Exchange jelenleg Ázsiában bővíti Real Time Data szolgáltatását (London Stock Exchange, 2018c). 2018. október 1-jétől az ázsiai kisbefektetők a régió már nyolc engedéllyel rendelkező forgalmazóján keresztül férhetnek hozzá a londoni tőzsde valós idejü piaci adataihoz. A Real Time Data szolgáltatás a befektetők számára értékes információkat szolgáltat a tőzsdén jegyzett és forgalmazott értékpapírokról, többek között a London Stock Exchange-ről, valamint a Borsa Italianáról. Simon Youdan, a londoni tőzsde üzletfejlesztési vezetője szerint Ázsia kontinense stratégiai fontosságú terület a London Stock Exchange számára, 
mivel a magas minőségű adatokhoz való valós idejü hozzáférés létfontosságú azok számára, akik a globális piacokra nagy kitettséget kívánnak elérni, és támogatják a platformot kereskedési tevékenységükkel (London Stock Exchange, 2018c).

Összefoglalva: a Turquoise, amely az AIM tulajdona, jelenleg Európa legnagyobb MTF-platformja, ahol a vállalatok részvényeinek kereskedése folyik. A Budapesti Értéktőzsde önálló kezdeményezése jóvoltából Magyarországon is létrejött egy MTF-piac, a BÉT Xtend, amelyen a kis- és középvállalkozások részvényei lesznek forgalomban. A következő fejezetben bemutatjuk, hogy miért éppen a kkv-k finanszírozása kapcsán tartottuk fontosnak az MTF-piacokat bemutatni.

\section{KIS- ÉS KÖZÉPVÁLLALKOZÁSOK ÉS AZ MTF}

A kis- és középvállalkozások számos kihívással szembesülnek működésük során, különböző külső és belső tényezőkkel kell megküzdeniük ahhoz, hogy jövedelmezőségüket hosszú távon fenntartsák és növeljék, illetve, hogy egyáltalán életben maradjanak. Kállay (2012) és Vágány-Kárpátiné-Daróczi (2011) alapján a kkv-k előtt álló főbb kihívások a következők:

- Kiszolgáltatottság. A kis- és középvállalkozások a vevőknek és a szállítóknak is kiszolgáltatottabbak, mint a nagy multinacionális vállalatok. A kkv-k ritkábban számítanak kiemelt stratégiai partnernek, és ez fontos lehet például egy fizetési haladékról szóló tárgyaláson.

- Alacsony tőkeellátottság. Gyakori, hogy a kis- és középvállalkozások nem rendelkeznek kellő mennyiségű saját tőkével és/vagy likviditási nehézségeik vannak.

- Finanszírozási nehézségek. Sok esetben a kkv-k nehezebben jutnak külső (akár saját, akár idegen) forráshoz, hitelfelvételkor például tipikusan kockázatos ügyfélnek minősülnek, és magasabb kamatokkal, illetve tranzakciós költségekkel szembesülnek.

- Alacsony kockázatviselö képesség. A kkv-k nem tudnak kockázatot vállalni, esetleg elviselni, hogy több éven át veszteségesek legyenek.

- Adóterhek. Kállay (2012) azt állapította meg, hogy a nagyobb cégek adóterhelése alacsonyabb.

Tanulmányunkban a finanszírozási nehézségek töltik be a központi szerepet. A vállalkozások megalapítása, működtetése tőkét igényel. A kkv-nak forrásbevonásra lehet szüksége például a humán erőforrás fejlesztése (több alkalmazott, meglévők képzése, képzettebbek felvétele) vagy az innováció elősegítése (új technológia bevezetése) érdekében, általában a piaci részesedésének fenntartásához vagy növeléséhez: a finanszírozási helyzet egy versenyképességi tényező. 
Az 1. táblázatban a vállalatok számára legfontosabb finanszírozási formákat gyüjtöttük össze. ${ }^{3}$

\section{1. táblázat}

Vállalatfinanszírozási lehetőségek

\begin{tabular}{ccc}
\hline & Belső finanszírozás & Külső finanszírozás \\
\hline & $\begin{array}{c}\text { Nyereség visszaforgatása } \\
\text { Amortizáció } \\
\text { Vagyonátcsoportosítás }\end{array}$ & Tulajdonosi tőke \\
& & Bankhitel \\
& & Kötvénykibocsátás \\
& & Lízing \\
& & Szállítói hitel \\
\end{tabular}

Forrás: Vasné (2006) leírása alapján saját szerkesztés

Belső finanszírozás esetén a vállalat külső segítség nélkül biztosítja a szükséges forrásait, külső finanszírozás esetén tőkeszükségletét „kívülről”, a tulajdonosok vagy a hitelezők segítségével elégíti ki. Nyilvános társaságok tőzsdén vagy MTF-piacon keresztül, nyilvános részvénykibocsátás útján hajthatnak végre tőkeemelést.

Számos ország küzd azzal a problémával, hogy a kkv-kban rejlő potenciált azok alacsony vagy nem megfelelő szerkezetű finanszírozottsága miatt nem képes kiaknázni a gazdaság. A London Stock Exchange Groupnak a kkv-król szóló éves kiadványában (London Stock Exchange Group, 2017) pénzügyi és gazdasági vezetők (például Toomas Töniste észt pénzügyminiszter vagy Roberto Gualteri, az Európai Parlament Gazdasági és Monetáris Bizottságának elnöke) fogalmazzák meg egybehangzóan, hogy a kkv-szektor a gazdaság gerince; a növekedés, az innováció és a munkahelyteremtés kulcsa Európában. Ugyanakkor azt is gyakran megjegyzik (például ugyanebben a kiadványban Xavier Rolet, a londoni tőzsde vezérigazgatója), hogy a hagyományos finanszírozási lehetőségek (tipikusan a hitelek) nem megfelelőek ennek a szektornak, amelynek sokkal inkább saját tő-

3 A gyüjtemény semmiképpen sem taxatív, és egyáltalán nem érinti az ún. mezzanine finanszírozási formákat. 
kés forrásra lenne szüksége, a tőzsdére lépésnél azonban rugalmasabb formában. Lényegében itt kapcsolódik össze a kkv-k története és az MTF-piacok fejlődése: több MTF is kifejezetten azért jött létre, hogy ennek a szektornak kínáljon finanszírozási platformot.

A platform lényege, hogy egyes kiemelt növekedési és innovációs potenciállal bíró kkv-k, amelyek tőkét kívánnak bevonni termékük vagy szolgáltatásuk fejlesztése céljából, a társasági részesedéseiket egy ún. másodlagos tőzsdére, MTF-re vezetik be. Teszik mindezt azért, mert az elsődleges tőzsdére való belépésre - a bevezetési követelmények miatt - még nem állnának készen.

A magyar kis- és középvállalatok finanszírozásában a belföldi hitelek és az uniós támogatások dominálnak (KSH, 2017). A válságot követően a korábbi években felhalmozott hitelállomány dinamikus leépítésének lehettünk tanúi, majd 2015től a hitelállomány újra növekedni kezdett. A Magyar Nemzeti Bank 2017-es értékelése szerint a fordulat bekövetkeztében nagy szerepet játszott a Növekedési Hitelprogram (NHP), amelynek 2013-as indulása után „2,811 Mrd Ft összegben kötöttek szerződéseket a programban részt vevő hitelintézetek 39254 mikro-, kis- és középvállalkozással” (MNB (2017, 2. o.). A tőzsdére lépés nem jellemzi a szektort, bár Magyarországon a tőzsdei kapitalizáció általában sem nevezhető magasnak, ugyanis a Global Economy 2018-as adatai szerint ez a GDP 22,68\%-át tette ki (The Global Economy, 2018).

Az utóbbi évtizedben hazánkban is teret nyertek a kockázati tőkealapok, amelyek szintén saját tőkés forrásbevonási lehetőséget nyújtanak a kkv-knak, ám sokszor olyan feltételekkel, amelyeknek a vállalatok nem szívesen tesznek eleget - például nem szeretnének jelentős tulajdonosi, irányítási jogokat átengedni a finanszírozónak.

\section{A BÉT XTEND PIAC SAJÁTOSSÁGAI}

A Budapesti Értéktőzsde (BÉT) legfontosabb céljai közt szerepel a tőkepiac fejlődésének, nemzetközi versenyképességének elősegítése, átlátható müködésének biztosítása, a befektetések biztonságának növelése és védelme, valamint a tökepiaci szereplők forrásbevonási lehetőségeinek szélesítése. Ehhez kapcsolódóan a Budapesti Értéktőzsde 2017 szeptemberében nyitotta meg első multilaterális kereskedési rendszerét, a BÉT Xtendet. Az Xtend olyan kis- és középvállalkozások számára nyújt tőkepiaci megjelenési és forrásbevonási lehetőségeket, amelyek jelentős üzleti növekedést terveznek, külső finanszírozást keresnek és képesek a multilaterális kereskedési piac követelményeinek eleget tenni. A hazai MTF-piacra olyan gazdasági vállalatok részvényeit várja a Budapesti Értéktőzsde, „amelyek gazdagítani tudják a BÉT részvénypalettáját, új befektetési sztorikkal, valamint elszánt üzleti 
ötletekkel keltik fel a potenciális befektetők érdeklődését és természetesen hosszú távon, a tőkepiacon képzelik el jövőjüket” (BÉT, 2018b, 1. o.).

A belépő vállalatok alacsonyabb díjakkal és egyszerübb feltételek szembesülnek, valamint speciális támogatókat is kapnak, de mégis a hagyományos tőzsdékhez hasonlóan szabályozott körülmények között (BÉT, 2018c). A könnyített feltételek lehetővé teszik, hogy fokozatosan szokják a tőzsdei transzparenciát, miközben ugyanolyan „megbecsült” kategóriában juthatnak a tőzsdére, mint a nagyobb cégek. Végh Richárd, a Budapesti Értéktőzsde elnök-vezérigazgatója szerint a BÉT hosszabb távú célja, hogy a fejlett kkv-k professzionális és transzparens működésű nagyvállalatokká fejlődhessenek a BÉT támogatásával (Végh, 2016).

Az Xtend - és általában az MTF-piacok specialitása -, hogy az ott részvényt kibocsátó vállalkozást egy kijelölt tanácsadó kapcsolja össze a befektetők csoportjával, amit általában a befektetői pool elnevezéssel illetnek. A 3. ábrán sematikusan bemutatjuk a szereplők kapcsolatait.

\section{3. ábra}

\section{Az MTF-piac felépítése és kapcsolati hálója}

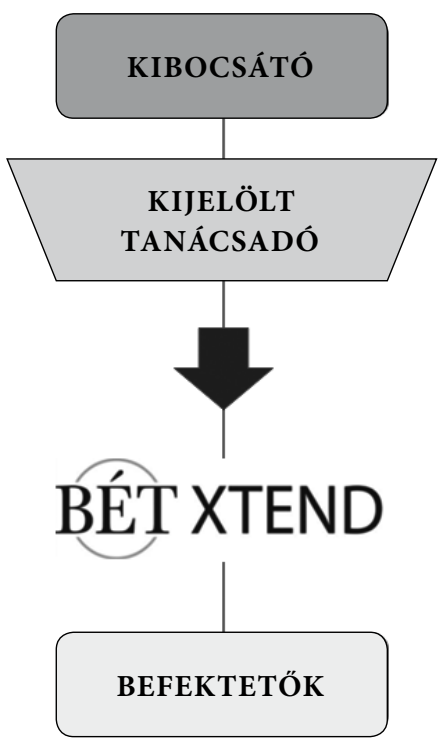

Forrás: saját szerkesztés

A multilaterális kereskedési piac legfontosabb szereplője a kibocsátó, vagyis a piacra újonnan belépő kis- és középvállalkozás. Az MTF-piac müködésében meghatározó a potenciális befektetői kör (úgynevezett „befektetői pool”) ahonnan a 
kibocsátók tőkét, hosszú távon forrást vonhatnak be. A potenciális befektetők és a kibocsátó egy meghatározó résztvevő segítségével, a kijelölt tanácsadó közreműködésével kerülnek kapcsolatba a BÉT Xtend-platformon keresztül. A kijelölt tanácsadó nemcsak a piacra lépésben, hanem a piaci jelenlét során is folyamatosan támogatja a kibocsátót, ami egyfajta garanciát jelent a befektetők számára. A kijelölt tanácsadó piacra lépés előtt átvilágítja a potenciális kibocsátót, támogatja annak tőzsdei felkészülését, előkészíti és lebonyolítja a tőkepiaci tranzakciót, majd a tranzakciót követően is jelen van, segíti a kibocsátót a nyilvános müködésben, évente nyilatkozik a kibocsátónak az Xtend piaci szabályzat szerinti megfelelőségéről. A BÉT Xtend piac szabályozási keretrendszerét a BÉT alakította ki, a piac felügyelete megoszlik a BÉT és az MNB között, a bevezetéshez szükséges információs dokumentum ellenőrzése, tartalmának meghatározása (5 millió kibocsátási összérték alatt) ezen a piacon szintén a BÉT feladata (BÉT, 2018d).

\subsection{Potenciális kibocsátók (fejlett kis- és középvállalkozások)}

Az elmúlt évtizedben a magyar kkv-szektorban tapasztalt forráshiányt a különböző EU-s források jelentősen csökkentették. Ehhez kapcsolódóan számos olyan cég van, amely az EU-s források és a Növekedési Hitelprogram ellenére sem tudott elegendő tőkét felhalmozni, ami akadályozza a további fejlődésben. Hosszú távon, kevésbé kedvező kamatkörnyezetben a hitelek mellett tőkepiaci forrásbevonási lehetőségekre is szükség van, a tőzsde „elöszobájaként” is említhető Xtend piac lehetőséget biztosít arra, hogy ez a lehetőség fejlettebb kkv-k számára is elérhető legyen a kedvező feltételrendszernek köszönhetően.

A lengyel, az angol és a skandináv MTF-piacokon jelenlévő kis- és középvállalkozások tanulmányozása alapján az alábbi iparágakban nagyobb a kkv-k tőzsdei jelenléte: telekommunikáció, (információs) technológia, szoftver- és számítógépipar, egészségügy, pénzügyi szolgáltatások, kőolaj és földgáz (London Stock Exchange, 2019a; 2018d). Ezen iparágak rendelkeznek olyan dinamikus fejlődési lehetőségekkel, amelyek vonzók lehetnek a tőkepiaci befektetők számára.

Mind nemzetközi, mind hazai szinten lényeges, hogy olyan vállalatok lépjenek tőzsdére, amelyek megfelelnek a befektetői bizalom magas minőségi követelményeinek, stabil teljesítményt nyújtanak, valamint növekedési potenciált biztosító üzleti stratégiával rendelkeznek, és így komoly befektetői érdeklődésre számíthatnak.

Az értékpapírok bevezetése az MTF-piacra kétféle módon történhet: egyrészről nyilvános részvénykibocsátással (IPO), másrészről úgynevezett technikai bevezetéssel. A technikai bevezetés olyan cégek számára kitűnő választás, amelyek zárt körben emelnek tőkét a tőzsdei bevezetés előtt, és vezetik be részvényeiket a 
tőkeemelés után. Ezt a nyilvános megjelenési formát nevezzük technikai bevezetésnek. Az IPO (Initial Public Offering) nyilvános ajánlattétel, amelyben a vállalat részvényeit eladják az intézményi befektetőknek. Az IPO-t a BÉT jegyzi be a Magyar Nemzeti Bank jóváhagyásával, így az adott társaság hivatalosan is a tózsdére kerül. A 4. ábra szemlélteti a lengyel, az angol és a skandináv piac 2017-es részvénykibocsátásainak számát. Amennyiben a kkv-k a piaci feltételeknek megfelelő üzleti stratégiát folytatnak, képesek a prémium - azaz a magasabb kategóriájú, szabályozott - piacra is belépni (Tamborski, 2015).

\section{4. ábra}

Részvénykibocsátások az egyes MTF-piacokon 2018-ban

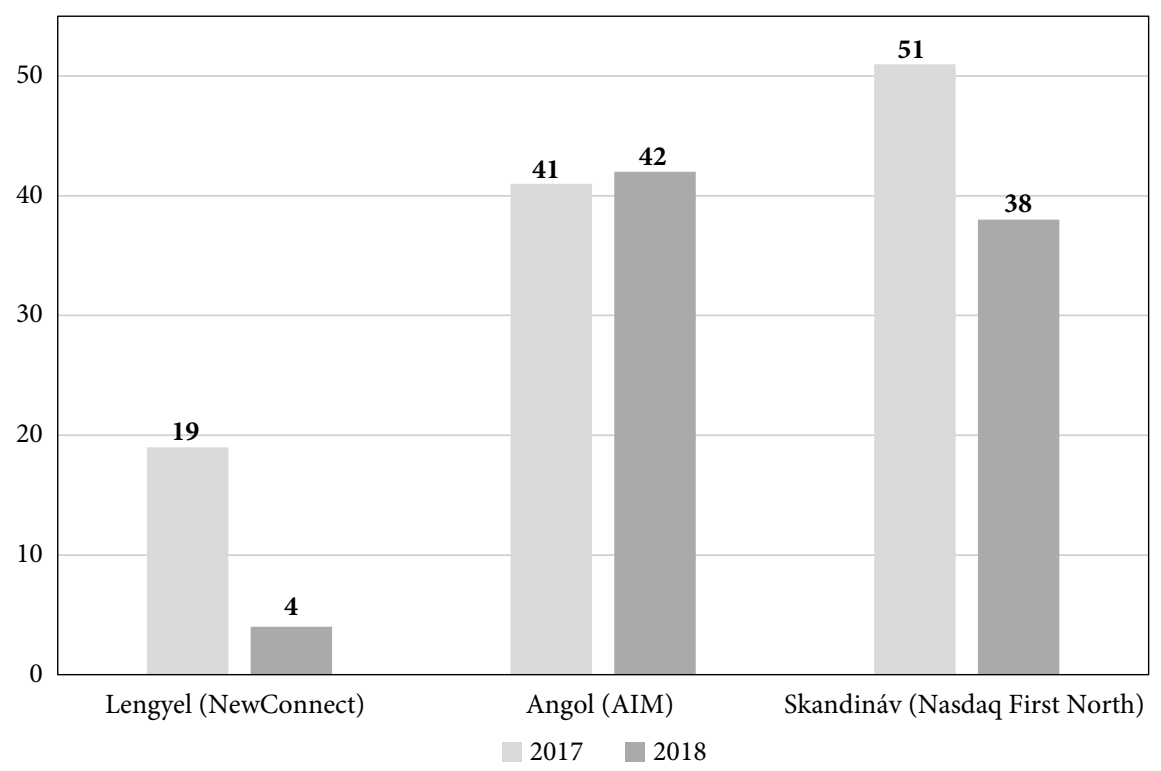

Forrás: saját szerkesztés az FESE (2019) és London Stock Exchange (2019b) alapján

\subsection{Kijelölt tanácsadó}

A multilaterális kereskedési piacok egyik jellegzetessége, hogy számos szabályozói feladat a helyi felügyeleti szervektől (például a Magyar Nemzeti Banktól) a piacüzemeltetőhöz - Magyarországon a Budapesti Értéktőzsdéhez - kerül. A tözsde rugalmasabban tud eljárni a bevezetési kérelmek elbírálásánál, ami gyorsítja a folyamatot, illetve az adminisztrációs költségek is kisebbek a szabályozott piacéhoz képest (BÉT, 2017). A különböző díjakat és költségeket a vezető MTF-piacok összehasonlításával az 5. fejezetben mutatjuk be. 
A felügyeleti szerepet az Xtend piacon a BÉT és az MNB közösen látja el. Annak érdekében, hogy a befektetői érdekek a lehető leghatékonyabban érvényesüljenek, illetve a kkv-k támogatást kapjanak a nyilvános müködésben, a legtöbb MTF-piac megköveteli a kijelölt tanácsadó hosszú távú jelenlétét és szerepvállalását. A kijelölt tanácsadó egyfelől biztosíték a befektetők számára, miközben támogatást biztosít a kibocsátónak, funkciója tehát kettős (BÉT, 2018e). A kijelölt tanácsadó a bevezetési folyamat elejétől segíti a vállalkozás felkészülését, így egyfajta garanciát jelent a befektetőknek, hogy megbízható és felkészült kibocsátók jelenjenek meg az MTF-piacon. A Hrabovszki Róberttel, az OTP Bank volt vezető tanácsadójával készített interjú alapján, a fö piactól eltérően itt a tanácsadó folyamatosan, a piacra lépést követően is támogatja a vállalat működését. Hogy pontosan mikor és hogyan támogassák a kibocsátókat, arra a nemzetközi gyakorlat alapján két lehetőség adódik: (i) a bevezetés után bizonyos ideig, például 1 évig; vagy (ii) a forgalomban tartás teljes időtartama alatt (London Stock Exchange, 2018e).

A kijelölt tanácsadó elemzi és értékeli a vizsgált cég tőzsdeképességét, illetve a vállalattal közösen állítja össze a bevezetési dokumentumokat - ezek tartalmazzák a cég és a kibocsátás adatait -, amelyeket majd a piaci üzemeltetőnek megküldenek. A tanácsadónak nyilatkoznia kell, hogy a dokumentáció megfelel az MTF által támasztott követelményeknek. Folyamatos tanácsadást nyújt továbbá a bevezetési folyamat során, szükség szerint képzéssel is támogatja a menedzsmentet, illetve az érintett alkalmazottakat (Peyrano, 2017).

Amennyiben a jegyzési követelmények teljesülnek, a felügyeleti és a piaci szervek jóváhagyták a kibocsátó által benyújtott információs dokumentumot, a regisztrációs kérelem jóváhagyását követően a kibocsátó bevezetésre kerül az Xtendre. A kijelölt tanácsadók körét a BÉT határozza meg, a kibocsátónak érvényes szerződésben kell állnia a BÉT által elfogadott, kijelölt tanácsadóval, ami egy hosszú távú együttműködés kezdetét jelenti. 2018-ban hivatalosan 16 kijelölt tanácsadó tevékenykedett a BÉT Xtend piacon (BÉT, 2018f).

\subsection{Befektetői pool}

A BÉT Xtend a kkv-k számára kialakított online kereskedési platform. A keresleti oldalon található befektetői kör és az általuk rendelkezésre bocsátott tőke meghatározó az MTF-piacok eredményessége és aktivitása szempontjából. A befektetők a következő szempontok mentén választanak a rendelkezésre álló tőkepiaci lehetőségek közül: (i) jövedelemtermelő képesség, (ii) kockázatok, (iii) befektetői várakozások, (iv) befektetés időhorizontja, (v) befektető kockázatvállalási hajlandósága, (vi) alternatív befektetési lehetőségek (Chikán, 2008). 
Magyarországon az elsődleges probléma a befektetői kultúra hiánya. Sajnálatos módon a tőkepiaci kockázatok és a lehetőségek nem megfelelő ismerete gátja az egészséges befektetői kereslet és kultúra kialakulásának. A befektetői védelem érdekében már az első MiFID-direktíva bevezette a befektetők szakmai megfelelősségének és szükség esetén alkalmasságának kötelező tesztjét; ennek tartalmi követelményrendszerét a MiFID II tovább erősítette (EU, 2014). Ennek következtében csak olyan befektetők kereskedhetnek, illetve léphetnek tőzsdére, akik rendelkeznek megfelelö pénzügyi alapokkal és szakmai tudással.

A Nemzeti Tőzsdefejlesztési Alap (NTfA) pénzügyi szempontból lehetőséget teremt azoknak a kis- és középvállalkozásoknak, amelyek a tőzsde „kapujában” helyezkednek el. Az NTfA elsődleges célja, hogy gördülékeny folyamatot biztosítson az MTF-piacra (BÉT, 2018f). A Nemzeti Tőzsdefejlesztési Alap kezelése a Széchenyi Tőkealap-kezelő Zrt. (SZTA) feladata. A Széchenyi, az Irinyi tőkebefektetési alapok, valamint a Tőzsdefejlesztési Alap a teljes magyar kkv-szektor tőkeági finanszírozását nyújtja. (A Nemzetgazdasági Minisztérium 2017 év végén az alap kezelésére nyílt pályázat keretében a Széchenyi Tőkealap-kezelő Zrt.-t választotta). Az NTfA összességében 13 milliárd forinttal támogatja a kkv-k tőzsdére lépését. Olyan vállalkozások részére nyújt tőkét, amelyek vállalják, hogy a közeljövőben megjelennek a BÉT Xtenden. Az alapkezelö egyrészről egy erős és kiegyensúlyozott befektetői kör kialakítására törekszik, továbbá arra, hogy évente körülbelül 4-8 kis- és középvállalkozást sikerüljön a hazai multilaterális kereskedési platformra bevezetni (Origo, 2018).

Az NTfA fontos ismérve, hogy co-investment ${ }^{4}$ formában von be magántőkét. Az alap teljes futamideje 12 év. Az alapkezelő 13 milliárd forintos támogatást nyújt, ami vállalkozásonként jellemzően 1 milliárd forint körüli összegek befektetését jelenti. Ugyanakkor számításba kell venni, hogy a pénz elosztása függ a jelentkezők számától. A cél az, hogy a támogatási összegek egyensúlyban legyenek. Az alap által biztosított összeg fedezi a pénzügyi tanácsadók és a papírok tőzsdére vitelével kapcsolatos költségeket, valamint a pénzügyi és jogi átvilágítás költségeit is. Fontosnak tartjuk még megjegyezni, hogy az NTfA zártkörüen müködő társaságokba fektet be, annak érdekében, hogy az adott cég rövid időn belül megjelenjen és elkezdhesse kereskedését a multilaterális platformon.

Tóth József - a Széchenyi Tőkealap-kezelő Zrt. tranzakciós igazgatója - szerint a kkv-knak nem kell attól tartaniuk, hogy az újonnan megjelenő tulajdonostárs átveszi az irányítást a cég fölött, az SZTA ugyanis maximum 49\%-os tulajdonosi

4 Jelen esetben a Széchenyi Tőkealap-kezelő magánbefektetőként közvetlenül egy müködő társaságnak nyújt pénzügyi segítséget. Mondhatjuk, hogy társbefektetőként jelenik meg az adott vállalkozásban. 
részesedést szerezhet meg. Az SZTA célja, hogy a kkv-k ne felvásárlási célpontok legyenek, hanem saját erőből legyen biztosított a növekedésük, és hogy lehetőleg minél többet exportáljanak.

\section{A BÉT XTEND PIAC ELÖNYEI}

A nemzetközi példákon már láthattuk, hogy az elmúlt években egy újfajta lehetőség nyílt a kis- és középvállalatok számára a tőkeági finanszírozás területén, ahol különböző kockázati tőkealapokon keresztül juthatnak forráshoz. Ezzel szemben mégis sok olyan kis- és középvállalat van a piacon, amelyek nem szívesen vonnak be olyan tulajdonosokat, akik aktívan részt szeretnének venni a cég mindennapi működésében. „A nyilvános működés lehetővé teszi, hogy a tőkebevonás során a vállalat egy szórtabb befektetői szerkezetet építsen ki, és a tulajdonosi irányítást csak az általa meghatározott mértékben adja át az új befektetőknek" (BÉT, 2018a, 1. o.). Az alábbi felsorolás (a BÉT, 2018g alapján) rámutat arra, hogy milyen lehetőséget foglal magába a BÉT Xtend.

1) Forrásbevonás

A nyilvános részvénykibocsátás növelheti a kibocsátó finanszírozási mozgásterét, így az adott vállalkozás dinamikusabb növekedést képes elérni. A tőkeági finanszírozás mellett a kibocsátás kedvezőbb feltételekkel juthat hitelági finanszírozáshoz is. Ennek egy példáját mutatjuk be a következőkben.

Az Xtend piac első kibocsátója a Megakrán Nyrt. volt 2018-ban, a kibocsátásban kijelölt tanácsadóként az MKB Bank Zrt. müködött közre. A Megakrán 1994-ben emeléstechnikával foglalkozó, egyszemélyes vállalkozásként indult. A vállalat forrását a válság utáni időszakban a Növekedési Hitelprogram biztosította, aminek a segítségével a cég a teljes gépparkját modernizálta. Az 5. ábra bemutatja a Megakrán árbevételének és EBITDA-mutatójának éves szintü alakulását. A cég 2015-ös évi 404 M Ft-os EBITDA-ja a válságból való kilábalását jelentette. Ezt követően a vállalat 15-20\%-os forgalomnövekedést ért el, így 2016-ban az árbevétele majdnem elérte az 1800 millió forintos szintet, és az EBITDA-mutatója is történelmi csúcsot döntött 650 millió forinttal. A Megakrán 2018-ban lépett az Xtend piacra, fejlesztéseihez tőkebevonást is igénybe véve. 


\section{5. ábra}

\section{A Megakrán Nyrt. árbevétel- és EBITDA-adatai (2015-2018)}

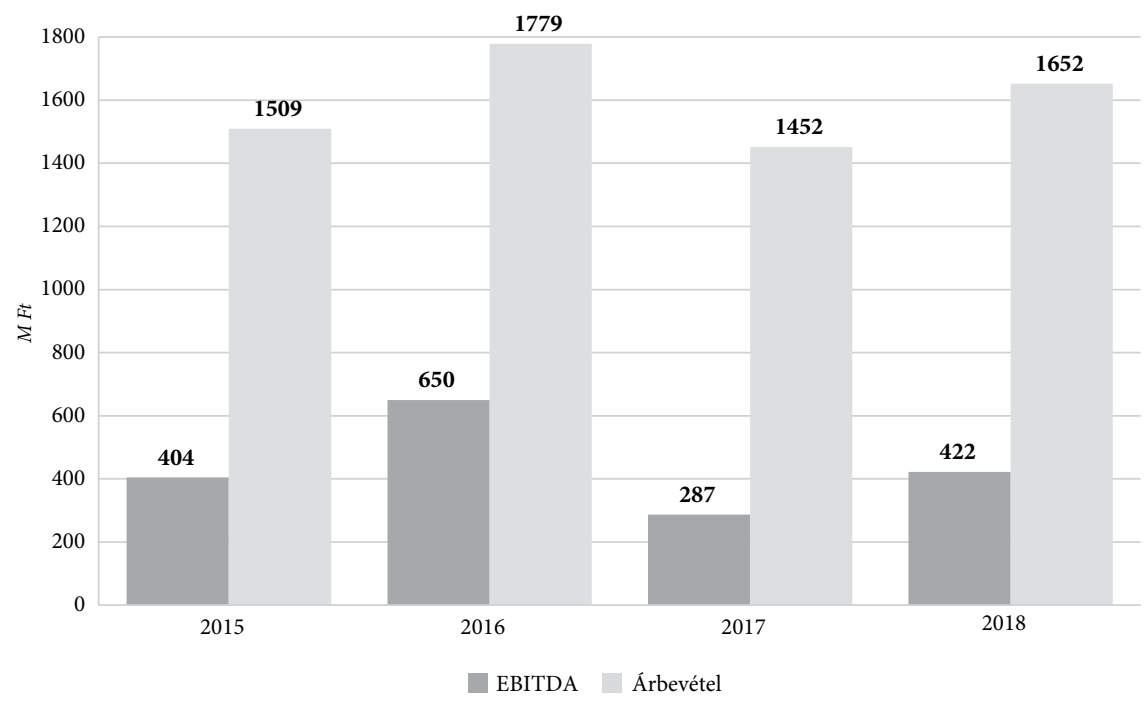

Forrás: saját szerkesztésű ábra a BÉT50 (2018) és e-beszamolo (2019) alapján

A nagymértékü növekedés a megvalósuló beruházások eredményességét támasztja alá. A megrendelések számának gyarapodásával egy újabb mérföldkőhöz érkezett a cég, méghozzá egy nagyobb méretű kapacitásbővítő beruházáshoz, amit már nem lehetett kizárólag bankhitelből finanszírozni. Ennek következtében csatlakoztak elsőként a BÉT Xtend piac Mentoring Programjához. 2018-ban ismét emelkedett a cég EBITDA-mutatója, az MTF-piacra való belépés hatását azonban csak hosszabb távon lehet majd megítélni.

2) Dolgozói, vezetői motiváció

Ha az adott társaság leányvállalattal vagy külföldi partnerrel rendelkezik, a részvényopció megszerzése fontos motiváló tényező.

3) Image-vagy brandépités

Egy cég tőzsdére lépésével erősödik a márkanév, valamint egy ismertebb vállalattal a partnerek is könnyebben kötnek üzletet. Kiváló példa erre a hazai ingatlanközvetítőként is ismert Duna House.

4) Kedvezőbb hitelfeltételek

A hitelintézetek (bankok) szemében is erősödik a társaság iránti bizalom, több hitelt és kedvezőbb feltételekkel tud így felvenni. 
5) A kontroll megtartása

A felépített érték realizálása, tehát a cégen belüli kontroll megtartása, de úgy, hogy annak egy részét a vállalkozás eladja. A cél, hogy a kontrolljogok a tulajdonosok/vezetők kezében legyenek a tőzsdére lépés után is.

6) Nyilvánosság

A tőzsdei cég müködése, árbevétele, adó utáni eredménye nyilvános a külföldi és belföldi partnerei számára. A nyilvánosan rendelkezésre álló üzleti adatok növelik a cég üzleti partnereinek bizalmát, így üzleti lehetőségeit is.

\section{7) Bizalom}

A vevők számára megnyugvást, egyfajta biztonságérzetet ad, valamint bizalmat gerjeszt bennük a tőzsdei jelenlét. Erre jó példa az UBM nevezetü cég, amelynek a napi értékpapír-forgalma szinte nulla, de mégis a tőzsdén van. Függetlenül attól, hogy illikvid a piacon, mégis élvezi a tőzsde nyújtotta előnyöket. A partnercégek, szállítók, vevők sokkal nagyobb bizalommal fordulnak hozzájuk, illetve több pénzt is fektetnek beléjük.

\section{A BÉT XTEND}

\section{ÉS A NEMZETKÖZI MULTILATERÁLIS PIACOK DÍJAI}

Az angol, a lengyel, a skandináv és a magyar MTF-piacok díjainak ismertetésével az a célunk, hogy az olvasó komplex képet kapjon arról: jelenleg egy kis- és középvállalkozónak milyen költségekkel kell kalkulálnia mind a hazai, mind a nemzetközi piacokon. Ennek megértésében nyújt segítséget a 6. ábra, ahol összehasonlítottuk a hazai BÉT Xtend és a már említett NewConnect (lengyel), London AIM Stock Exchange (angol) és Nasdaq First North (skandináv) MTF-piacok fizetendő díjait. 


\section{6. ábra}

\section{Az MTF-piacok költségeinek összehasonlítása (E Ft)}

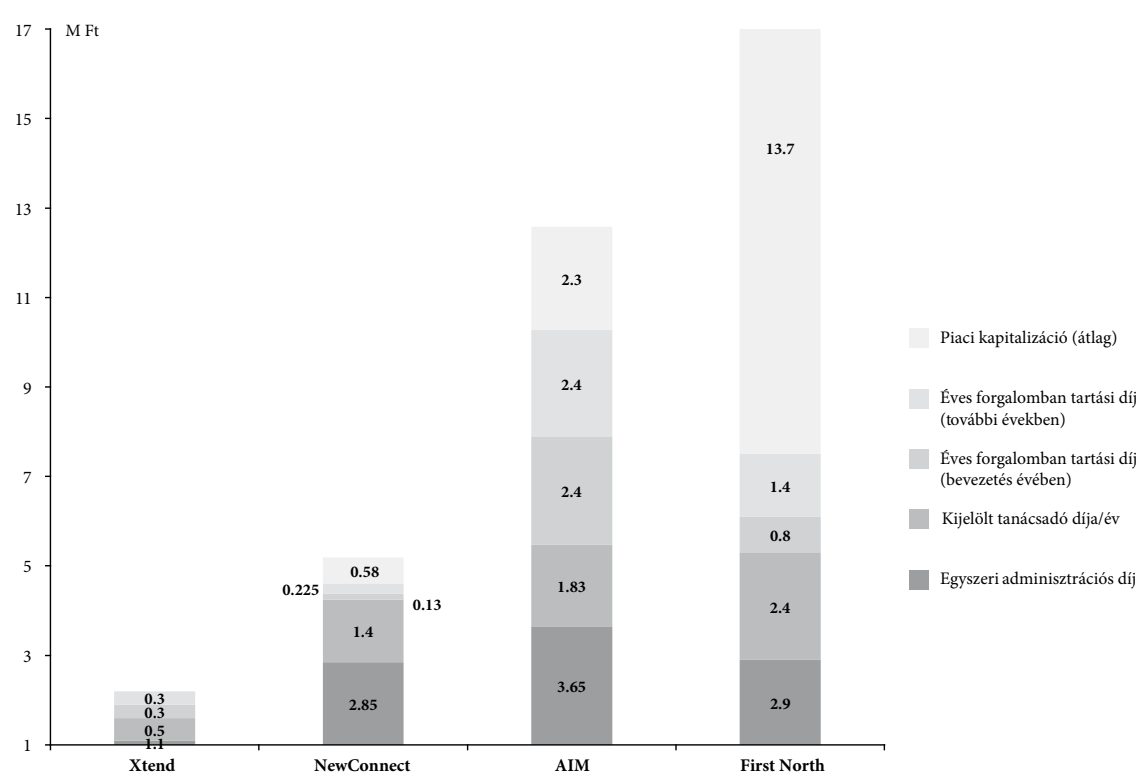

Forrás: Saját szerkesztés BÉT (2019), London Stock Exchange (2019c), Nasdaq First North (2019b), NewConnect (2019b) alapján

A nem magyar devizában denominált multilaterális piacok költségeit a 2019. február 4-i árfolyamon ${ }^{5}$ váltottuk át forintra. A költségelemek közül a piaci kapitalizációs díj szorul némi magyarázatra. A fent említett piacokon különböző piaci kapitalizációs kategóriákat vagy „sávokat” határoznak meg. A dijtétel egy év $v^{6}$ hónapjainak piaci kapitalizációs átlagán alapszik, azaz az adott piacon található vállalatok adott hónapban elért piaci kapitalizációit számszerüsítik, majd átlagolják. A díj kiszámítási módja minden országban különbözö, és mértéke attól függ, hogy melyik sávba esik bele az adott MTF átlagos kapitalizációja (London Stock Exchange, 2019c; Nasdaq First North, 2019b; NewConnect, 2019b). A piaci kapitalizáció éves díját akkor sem térítik vissza, ha egy vállalatot az adott évben eltávolítanak, vagy esetleg a cég kilép az MTF-piacról.

A 6. ábrán látható, hogy a legnagyobb díjtétellel a skandináv Nasdaq First North piac rendelkezik. A piaci kapitalizáció szempontjából a 2018-as, míg a többi díj-

$51 \mathrm{EUR}=319 \mathrm{HUF}, 1 \mathrm{GBP}=365 \mathrm{HUF}, 1 \mathrm{PLN}=75 \mathrm{HUF}, 1 \mathrm{USD}=279 \mathrm{HUF}$

6 Piaconként eltérő lehet, hogy ez megegyezik-e a naptári évvel. 
tétel esetében a 2019-s időszakot nézve egy kis- és középvállalatnak $(2,9+2,4+$ 0,8 + 1,4 + 13,7) 21,2 millió Ft-ot kell megfinanszíroznia a Nasdaq First North piacán (Nasdaq First North, 2019b). A második helyen a legrégebbi múlttal rendelkező, londoni AIM található, ahol éves szinten átlagosan 12,58 millió Ft (London Stock Exchange, 2019c), míg a NewConnecten „mindössze” 5,19 millió Ft (NewConnect, 2019b) a kkv-k átlagos díjterhe. A BÉT Xtend piacon az adminisztrációs díj, a kijelölt tanácsadói díj és az éves forgalomban tartási díj összege 2,2 millió Ft. Piaci kapitalizációjáról még nincs évesített adat, mivel a kereskedés 2018. 12. 04-én indult el.

\section{ÖSSZEFOGLALÁS}

Tanulmányunkban összegyüjtöttük, hogy miért lehet előnyös a kis- és középvállalkozói szektor számára a multilaterális kereskedési piacra csatlakozni és a belépési feltételeknek megfelelni. Bemutattuk a már több éve működő angol, lengyel és skandináv multilaterális piac fejlődési történetét, illetve összehasonlítottuk a hazai BÉT Xtend és a nemzetközi piacok tőzsdei díjait.

\section{HIVATKOZÁSOK}

Asyngier, R. (2014): NewConnect in comparison with multilateral trading facilities in Europe. Irregularities in the functioning of the Polish MTF market. Annales Universitatis Mariae Curie-Skłodowska, XLVIII(1), Lublin, p. 10-17. http://bazhum.muzhp.pl/media// files/Annales_Universitatis_Mariae_Curie_Sklodowska_Sectio_H_Oeconomia/Annales_ Universitatis_Mariae_Curie_Sklodowska_Sectio_H_Oeconomia-r2014-t48-n1/Annales_ Universitatis_Mariae_Curie_Sklodowska_Sectio_H_Oeconomia-r2014-t48-n1-s9-23/Annales_Universitatis_Mariae_Curie_Sklodowska_Sectio_H_Oeconomia-r2014-t48-n1-s9-23.pdf, https://doi.org/10.17951/h.2014.48.1.9 (letöltve: 2018.12.06.).

BÉT (2017): BÉT Xtend - Középvállalatokra kalibrálva. Budapest, https://www.bet.hu/pfile/ file?path=/site/Magyar/Dokumentumok/Kibocsatok/Xtend/BET-Xtend-leporello-press.pdf (letöltve: 2018.03.10.).

BÉT (2018a): Előnyök a BÉT Xtend piacon. Budapest, https://www.bet.hu/Kibocsatok/kozepvallalatiszolgaltatasok/xtend/Elonyok-a-BET-Xtend piacon (letöltve: 2018.03.03.).

BÉT (2018b): Élet az Xtend-en. Budapest, https://www.bet.hu/Kibocsatok/kozepvallalatiszolgaltatasok/xtend/Elet-az-Xtend-en (letöltve: 2018.03.02.).

BÉT (2018c): Szabályzatok. Budapest, https://www.bet.hu/Kibocsatok/kozepvallalati-szolgaltatasok/ xtend/Szabalyzatok (letöltve: 2018.03.02.).

BÉT (2018d): Xtend szemben az egyéb tőzsdei kategóriákkal. Budapest, https://www.bet. hu/Kibocsatok/kozepvallalati-szolgaltatasok/xtend/Xtend-szemben-az-egyeb-tozsdeikategoriakkal (letöltve: 2018.03.02.).

BÉT (2018e): Kik a kijelölt tanácsadók. Budapest, https://www.bet.hu/Kibocsatok/kozepvallalatiszolgaltatasok/xtend/Kik-a-kijelolt-tanacsadok (letöltve: 2018.03.03.). 
BÉT (2018f): Nemzeti Tőzsdefejlesztési Alap. Budapest, https://www.bet.hu/Kibocsatok/ kozepvallalati-szolgaltatasok/nemzeti-tozsdefejlesztesi-alap (letöltve: 2018.03.03.).

BÉT (2018g): Lehetőség a középvállalatoknak. Budapest, https://www.bet.hu/Kibocsatok/ kozepvallalati-szolgaltatasok/xtend/Lehetoseg-kozepvallalatoknak (letöltve: 2018.03.03.).

BÉT (2019): Díjak. Budapest, https://www.bet.hu/Kibocsatok/kozepvallalati-szolgaltatasok/xtend/ Tovabbi-fontos-tudnivalok (letöltve: 2019.03.03.).

BÉT50 (2018): BÉT50 - Ötven hazai vállalat sikertörténete. Budapest: BÉT, https://www.bet.hu/ Kibocsatok/bet50/2018/vallalatok/outon-a-tozsdere-megakran-zrt (letöltve: 2018.12.22.).

Chiкán Atтila (2008): Vállalatgazdaságtan. 4. átdolgozott, bővített kiadás. Budapest: Aula Kiadó.

Elektronikus Beszámoló Portál (2019): e-beszamolo. Céginformációs és az Elektronikus Cégeljárásban Közreműködő Szolgálat, Igazságügyi Minisztérium, https://e-beszamolo.im.gov.hu/oldal/kereses_merleglista?f=ThkJU\%2bVcUZiG9z6iZOjENw\%3d\%3d\&so=1https://e-beszamolo. im.gov.hu/oldal/kereses_merleglista?f=ThkJU\%2bVcUZiG9z6iZOjENw\%3d\%3d\&so=1 (letöltve: 2019.04.29.).

EU (2004): MiFID I direktíva. Az Európai Parlament és a Tanács 2004/39/EK irányelve. https://eurlex.europa.eu/legal-content/HU/TXT/HTML/?uri=CELEX:32004L0039\&from=HU (letöltve: 2018.02.14.).

EU (2014): MiFID II direktíva. Az Európai Parlament és a Tanács 2014/65/EU irányelve. https:// eur-lex.europa.eu/legal-content/HU/TXT/PDF/?uri=CELEX:32014L0065\&from=EN (letöltve: 2018.02.14.)

FESE (2019): IPO database. Federation of European Securities https://fese.eu/statistics/ (letöltve: 2019.04.28.).

KÁLlAY LÁszló (2012): Kkv-szektor: versenyképesség, munkahelyteremtés, szerkezetátalakítás. Mühelytanulmány, TM 58. BCE Vállalatgazdaságtan Intézet, Versenyképesség Kutató Központ, http://edok.lib.uni-corvinus.hu/458/1/TM58_Kallay.pdf (letöltve: 2018.03.11.)

KSH (2017): A kis- és középvállalkozások jellemzői. Központi Statisztikai Hivatal, http://www.ksh. hu/docs/hun/xftp/idoszaki/pdf/kkvl7.pdf (letöltve: 2018.12.16. 16:05) London Stock Exchange Group (2017). 1000 Companies to Inspire Europe. https://www.lseg.com/resources/10oocompanies-inspire/2017-report-100o-companies-europe (letöltve: 2018.03.16.)

London Stock Exchange (2018a): AIM. www.lseg.com/aim (letöltve: 2018.02.26.).

London Stock Exchange (2018b): AIM Securities on Turquoise. https://www.lseg.com/turquoise/aim (letöltve: 2018.07.26.).

London Stock Exchange (2018c): London Stock Exchange Group Expands Real Time Data Service in Asia. https://www.lseg.com/resources/media-centre/press-releases/london-stock-exchangegroup-expands-real-time-data-service-asia (letöltve: 2018.07.26.).

London Stock Exchange (2018d): Identifies 1000 most dynamic SME's in Europe. https://www.lseg. com/resources/media-centre/press-releases/london-stock-exchange-group-identifies-1000most-dynamic-smes-europe (letöltve: 2018.02.26.).

London Stock Exchange (2018e): London AIM Market Nominated Advisor. https://www. londonstockexchange.com/companies-and-advisors/aim/advisers/advisers.htm (letöltve: 2018.02.26.)

London Stock Exchange (2019a): Historical AIM Statistics. https://www.londonstockexchange.com/ statistics/markets/aim/aim.htm (letöltve: 2019.04.23.).

London Stock Exchange (2019b): New and Further Issues. htts://www.londonstockexchange.com/ statistics/new-issues-further-issues/new-issues-further-issues.htm (letöltve: 2019.04.24.)

London Stock Exchange (2019c): Fees for companies and nominated advisers. https://www. londonstockexchange.com/companies-and-advisors/aim/publications/aim-fees-forissuers-2019.pdf. 
MNB (2017): A növekedési hitelprogram eredményei. Magyar Nemzeti Bank, http://www.mnb.hu/ letoltes/a-novekedesi-hitelprogram-eredmenyei-honlapra-20170613.pdf (letöltve: 2018.03.24.).

Nasdaq First North (2019a): Companies Listed on Nasdaq First North. http://www.nasdaqomxnordic. com/shares/listed-companies/first-north (letöltve: 2019.04.25.).

Nasdaq First North (2019b): Equity Issuers on Nasdaq First North. https://business.nasdaq.com/ media/First-North-Price-List-2019_tcm5044-21010.pdf (letöltve: 2019.03.06.).

Nasdaq OMX Nordic (2018): Nasdaq's story. https://business.nasdaq.com/discover/nasdaq-story/ index.html (letöltve: 2018.03.06.).

NewConnect (2019a): NewConnect Statistics. https://newconnect.pl/statistics-periodic (letöltve: 2019.03.06.).

NewConnect (2019b): Market data. https://newconnect.pl/market-data (letöltve: 2019.04.26.).

Origo (2018): A Széchenyi Tőkealap-kezelő lett a Nemzeti Tőzsdefejlesztési Alap kezelője. http://www. uzletresz.hu/sikerek/20180103-a-szechenyi-tokealap-kezelo-lett-a-nemzeti-tozsdefejlesztesialap-kezeloje.html (letöltve: 2018.03.16.)

Peyrano, Luca (2017): ELITE - Connecting companies with capital. BÉT, https://www.bet. hu/Kibocsatok/kozepvallalati-szolgaltatasok/ELITE-program/ELITE-program (letöltve: 2018.03.18.).

TAmborski, Pawel (2015): Summary of the activities of Poland's first alternative trading platform. NewConnect Report, Warsaw Stock Exchange, p. 4-22. http://docplayer.net/47463678Newconnect-report-2015-summary-of-the-activities-of-poland-s-first-alternative-tradingplatform.html (letöltve: 2018.03.16.).

The Global Economy (2018): Stock market capitalization, percent of GDP - country rankings. https:// www.theglobaleconomy.com/rankings/Stock_market_capitalization/ (letöltve: 2018.03.17.).

Tóth József (2018): Nemzeti Tőzsdefejlesztési Alap (NTfA). Előadás a BÉT50 2018, középvállalatok csúcstalálkozója konferencián (2018.09.20.), https://www.bet.hu/Kibocsatok/bet50/2018/bet50kozepvallalatok-csucstalalkozoja-harmadszor-is.

VÁGÁNy JUdit - KÁrpÁTINÉ DARóczi Judit (2011): A gazdasági világválság kihívásai és a kilábalás lehetőségei a kkv-k számára. https:/www.researchgate.net/publication/277140417_A_ gazdasagi_vilagvalsag_kihivasai_es_a_kilabalas_lehetosegei_a_kkv-k_szamara (letöltve: 2018.03.16.).

VASNÉ Botár ÁGNes (2006): A vállalkozások tipikus külső finanszírozási forrásai (hitel, lízing, értékpapírok). http://kepzesevolucioja.hu/dmdocuments/4ap/19_0001_017_101215.pdf (letöltve: 2018.09.10.).

VÉGH RicháRD (2016): Növekedés a tőzsdével - ELITE Program, együttműködésben a BÉTtel. https://www.bet.hu/Kibocsatok/kozepvallalati-szolgaltatasok/ELITE-program/ELITEprogram (letöltve: 2018.03.14.). 